\title{
Substantiation of Improvements for the Bearing Structure of an Open Car to Provide a Higher Security during Rail/Sea Transportation
}

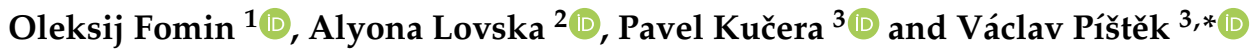 \\ 1 Department of Cars and Carriage Facilities, State University of Infrastructure and Technologies, \\ Kyrylivska Street, 9, 04071 Kyiv, Ukraine; fomin_ov@gsuite.duit.edu.ua \\ 2 Department of Wagon Engineering and Product Quality, Ukrainian State University of Railway Transport, \\ Feuerbach Square, 7, 61050 Kharkiv, Ukraine; alyonalovskaya@kart.edu.ua \\ 3 Institute of Automotive Engineering, Brno University of Technology, Technická 2896/2, \\ 616-69 Brno, Czech Republic; kucera@fme.vutbr.cz \\ * Correspondence: pistek.v@fme.vutbr.cz; Tel.: +420-541-142-271
}

Citation: Fomin, O.; Lovska, A.; Kučera, P.; Píštěk, V. Substantiation of Improvements for the Bearing Structure of an Open Car to Provide a Higher Security during Rail/Sea Transportation. J. Mar. Sci. Eng. 2021, 9, 873. https://doi.org/10.3390/ jmse9080873

Academic Editor: Valentin Heller

Received: 15 July 2021

Accepted: 10 August 2021

Published: 13 August 2021

Publisher's Note: MDPI stays neutral with regard to jurisdictional claims in published maps and institutional affiliations.

Copyright: (c) 2021 by the authors. Licensee MDPI, Basel, Switzerland. This article is an open access article distributed under the terms and conditions of the Creative Commons Attribution (CC BY) license (https:// creativecommons.org/licenses/by/ $4.0 /)$.
Abstract: This article presents the most frequent damage in the bearing structure of a rail car during rail/sea transportation. The study includes load modes for the bearing structure of an open car such as unloading with a grab and transportation by a train ferry. It was found that the most vulnerable element of the bearing structure of an open car during unloading with a grab is the top cord. The authors suggest applying a viscous material (an elastomer) to reinforce the top cord. This solution was confirmed by means of a strength calculation, whose results showed the efficiency of the solution. The bearing structure of an open car during the train ferry transportation can be protected by mounting special fixation units on the bolster beams. The geometry of such units was chosen according to that of a chain binder. The results of the strength calculation demonstrated that the strength of the bearing structure of an open car was provided with the application of the fixation units suggested. The article also presents the results of the experimental determination of the strength of the improved bearing structure of an open car based on the finite element method and full-scale bench testing. The research conducted might be used by those who are interested in higher operational efficiency of rail cars during rail/sea transportation.

Keywords: bearing structure; open car; security strength; security; train ferry transportation; transport mechanics

\section{Introduction}

A higher efficiency of international transportation can be maintained by the mutual cooperation of transport operators. Nowadays, the most popular are rail and maritime transportation.

The research into the working conditions of transport means during international rail/sea transportation demonstrated that the most vulnerable element is the bearing structure of a rail car. The damage is caused by the loads that exceed the allowable values. Moreover, it should be noted that the bearing structure of a car is not suited to all operation modes, e.g., the unloading with a grab, transportation by a train ferry, etc.

This leads to damage of the bearing structure of a rail car, requiring off-schedule repairs, additional maintenance expenditures, etc. Therefore, there is an urgent need to develop the technique for the customisation of the bearing structure of a rail car for effective operation during international rail/sea transportation.

The strength of the bearing structure of an improved Zans car with better technical and economic characteristics is determined in [1,2]. The strength calculation was made with the finite element method. The results of the calculations confirmed the efficiency of the designing solutions taken. It should be noted that the designing stage did not include measures aimed at the structural reliability of rail cars during rail/sea transportation. 
The special features of the theoretical research into the optimisation of the bearing structure of a freight car were studied in [3] by means of the finite element method. An open car BOXN25 was taken as the prototype. However, these measures do not provide secure transportation by train ferries.

The strength of the bearing structure of a car intended for intermodal transportation is determined in [4]. The design model was built in accordance with the PN-EN standards. The calculation was made with the finite element method.

The analysis of the theoretical and experimental research into the strength characteristics of rail vehicles by an example of the centre sill of a freight car is given in [5] in which the authors applied modern software programs. This approach turned out to be effective and efficient, i.e., the authors found the right area in their research. However, the calculation did not include the potential loads on a car during rail/sea transportation.

A selection of the structural solutions for elements of a car with a low tare mass is conducted in [6]. The authors made a comparative analysis of the strength characteristics, durability and stability of the bearing structure with the minimum mass and produced of different materials. An analysis of the causes of crack development in the bearing structure of a car frame is given in [7]. The study presents the method used for identifying some causes of crack development near weld joints. The calculation was made for the frame of a Sgmns wagon. However, the research did not include the operational conditions for the rail cars during rail/sea transportation.

Strength research of the bearing structure of a car under the least favourable modes of loading and shunting impacts is presented in $[8,9]$. The study describes the measures for protecting the bearing structure of a rail car. However, the authors did not consider the issue of the transportation of cars by train ferries.

Improvement of the method of calculating the strength of the upper strapping of the side walls of the gondola car body is presented in [10]. Refined calculation schemes are proposed that take into consideration the unloading of frozen cargo from an open-top car on a car dumper. It is important to say that the work does not outline the prospects for improving the supporting structure of the gondola car to ensure its durability in operation. The peculiarities of using the theory of the optimal design of the supporting structure of the body of a dead-bottom gondola car are highlighted in [11]. The results of the research made it possible to determine the optimal configuration of the gondola car unloading bins. At the same time, the authors have not proposed design solutions aimed at ensuring the strength of the gondola car supporting structure under the most unfavourable operating conditions.

The choice of structural solutions for the elements of cars with a low tare weight is carried out in [12]. As a methodology, a comparative assessment of the strength, durability and stability indicators of the supporting structure of the minimum mass made of different materials was used. However, in this work, the most unfavourable modes of loading the supporting structures of gondola cars-unloading with a grab bucket, as well as transportation on railway ferries-were not included.

Determination of the load of the gondola car body under operating conditions and ways of improving its design to ensure strength and service life are considered in [13]. To ensure the strength of the components of the body structure, it is proposed to strengthen it with stiffeners, as well as the use of high-strength steel in their manufacture. An improvement of the gondola car design to ensure its safety during loading and unloading operations is carried out in publications [14,15]. The proposed improvements are aimed at changing the geometry of the most loaded components of the supporting structure. The results of the strength calculation confirmed the feasibility of the decisions taken. At the same time, the authors of these works did not take into account the loads that can act on car bodies during transportation on rail ferries.

A study of the dynamics of the load-bearing structures of wagons during transportation by rail ferries by sea is carried out in [16]. In this case, the dynamic load that acts on the car during the oscillations of the railway ferry was determined by differentiating the law of movement of the sea wave. The studies carried out became the basis for the 
formation of requirements for the calculation of wagons for transportation by sea [17,18]. At the same time, the calculations for the strength of the load-bearing structure of the car, as well as the improvement of its design for the reliability of fixing on the deck, have not been considered in the work.

In [19], the questions of fastening the load-bearing structures of wagons on the decks of railway ferries are dealt with. The requirements for multiple vehicle mountings are given. Features of the construction and application of multi-turn means for securing cars on ferry decks are considered in [20]. The safety requirements for using these fasteners are given. However, the authors did not take into account the effects of the fasteners under consideration on the strength of the load-bearing structures of the wagons during sea transport.

In [21,22], a study of the dynamic load of a container as part of combined trains during transportation on rail ferries is carried out. The conditions for the safe transportation of containers have been determined, taking into account the typical scheme of interaction with the wagon. Measures are proposed to ensure the stability of containers on wagons during transportation by ferries. However, the data research was carried out on combined trains.

The peculiarities of the carriage of wagons on railway ferries without running gears are highlighted in [23]. The advantages of the proposed technology for the transportation of wagons are given, as well as the prospects for its development. It is important to say that the authors did not consider the issues of dynamic load and strength of car bodies, taking into account the considered technology.

Analysis of the literature [1-23] allows us to conclude that the issues of studying the load and ensuring the strength of the load-bearing structures of cars during operation in railway-water communication require further development. This makes it necessary to conduct research in this direction, which will improve the efficiency of the operation of wagons in the railway-water communication.

\section{Objective and Tasks of the Research}

The purpose of this research is to substantiate the measures to improve the bearing structure of an open car to provide a higher security during rail/sea transportation. To achieve this purpose the following tasks were set:

- to suggest the measures for a higher strength of the bearing structure of a car during unloading with a grab;

- to suggest measures for the tight securing of the bearing structure of a car on the train ferry deck;

- to conduct experimental research into the strength of the improved bearing structure of a car.

\section{Determination of Causes of Damage to the Bearing Structure of a Car during Rail/Sea Transportation}

The unloading of gondola cars in ports is carried out by means of grabs (Figure 1).

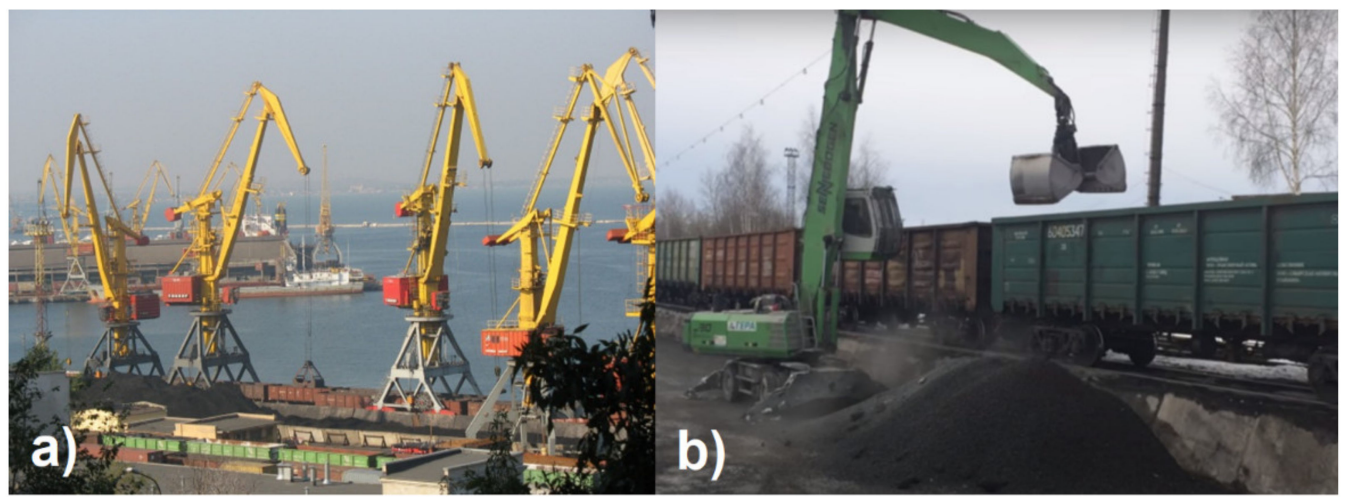

Figure 1. Unloading of the car with a grab (a) overhead grab; (b) power grab. 
It should be mentioned that this unloading method may cause serious damage to structural elements of the body because the geometry of the body is not fitted to interaction with the grab. The most frequent damage to the bearing structure of a body during unloading with a grab are cracks, deformations, ruptures of the top cord and weld joints, etc. Additionally, the top cord of the frame suffers the most (Figure 2).

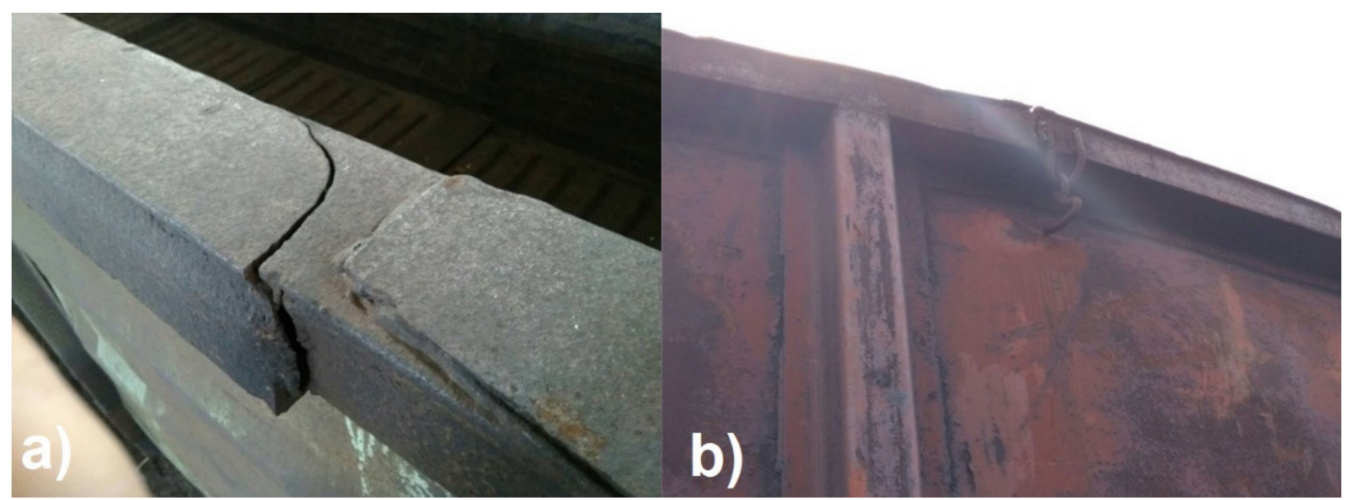

Figure 2. Damage to the top cord of a car body during unloading with a grab (a) crack in the top cord; (b) rupture in the top cord.

The open car is also badly damaged during train ferry transportation because its bearing structure is not suited for interaction with the lashing devices applied for unloading (Figure 3).

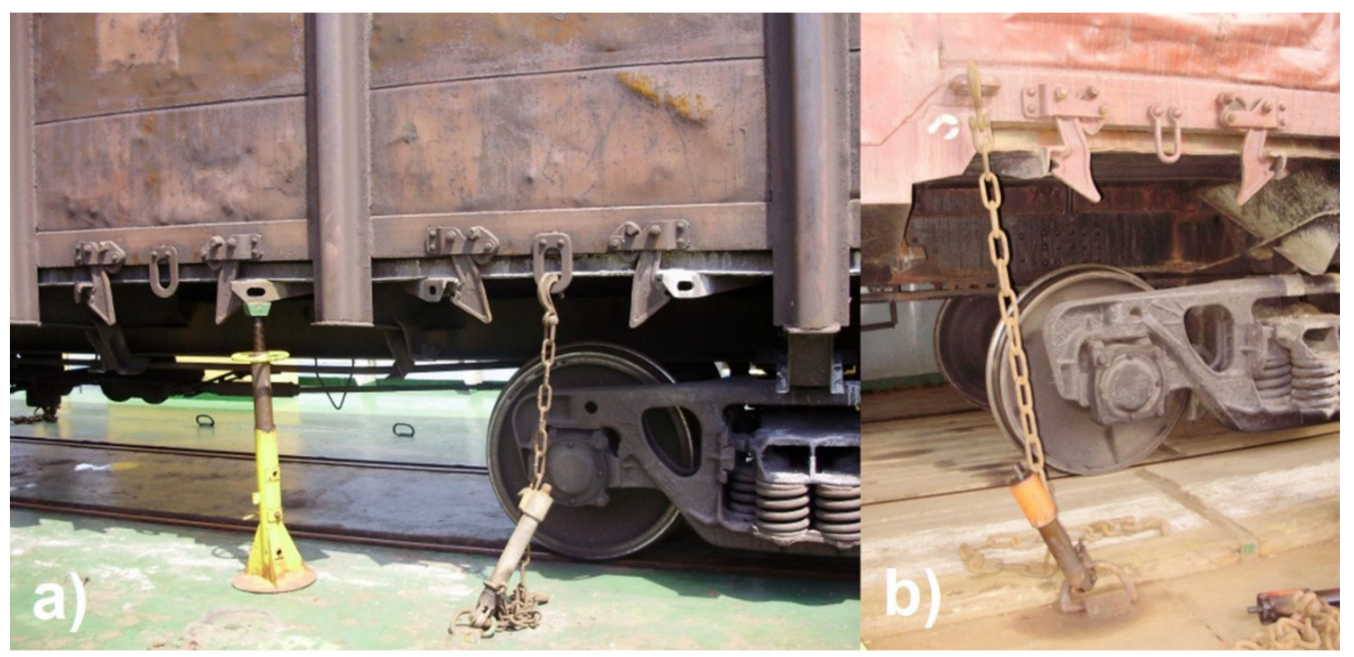

Figure 3. Securing of a rail car on the train ferry deck (a) Geroi Plevny; (b) Greifswald.

The car elements can also be damaged due to sea disturbance (Figure 4). Thus, the car on the train ferry deck may lose its stability or even overturn. As a result, the train ferry can lose stability and sink.

Therefore, there is a need to improve the bearing structure of a rail car to protect it during rail/sea transportation. 


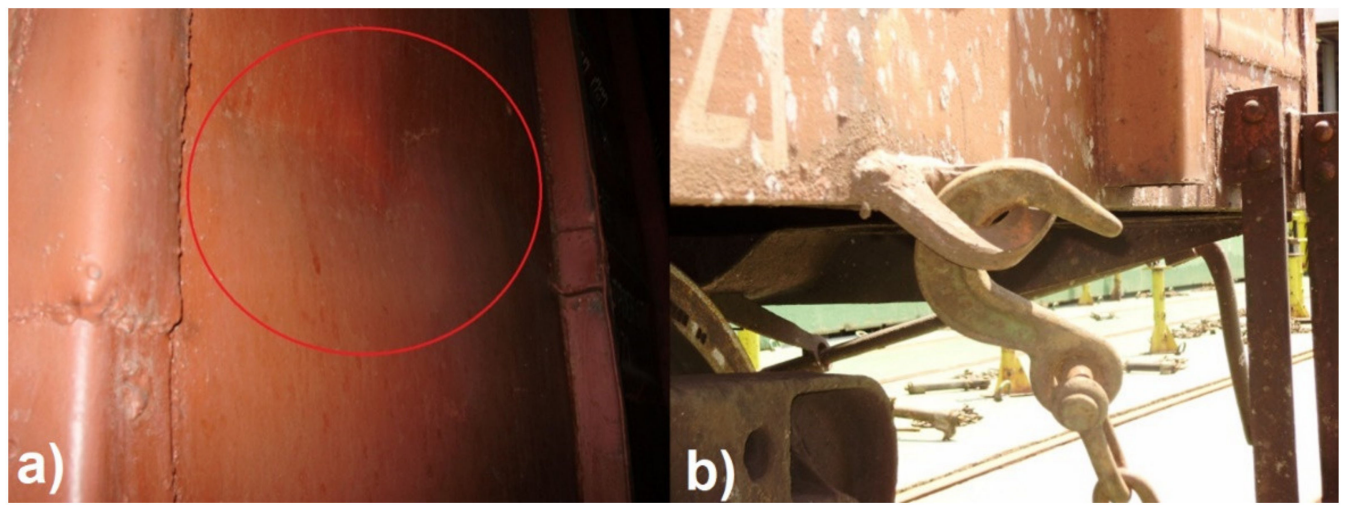

Figure 4. Damage to the elements of the bearing structure of a rail car (a) deformation of the top cord; (b) deformation of the tow brace.

\section{Substantiation of Improvements to Protect the Bearing Structure of an Open Car during its Unloading with a Grab}

This research deals with the introduction of viscous elements in the bearing structure of an open car in order to decrease the loads during unloading with a grab in seaport terminals. An elastomer was suggested as the viscous material and the damper in the conditions of impact interaction between the grab and the top cord.

To study the dynamic loading of the supporting structure of the gondola car body during impact interaction with the grab bucket, a differential equation of the body displacements was compiled (Equation (1)). The design scheme is shown in Figure 5. The moment of inertia of the body was considered as the inertial coefficient. The potential component of the energy balance was considered through the rigidity of the spring sets on which the gondola car body rests.

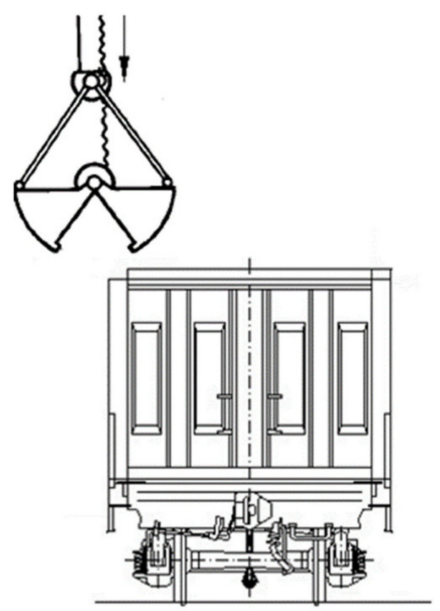

Figure 5. Computational model scheme of a gondola car.

The created mathematical model of the dynamic load of the supporting structure of the gondola car body during impact interaction with the grab bucket has the following form:

$$
I_{k} \ddot{\varphi}+C \frac{B}{2} \varphi=M_{g b}-\beta \frac{B}{2} \dot{\varphi},
$$

where $I_{k}$ is the moment of inertia of the gondola car body; $C$, the spring kits stiffness; $B$, the width of the gondola car body; $\beta$, the coefficient of the viscous material damping with which the upper rail of the car is filled; $M_{g b}$, the moment of forces that occurs when the grab bucket interacts with the supporting structure of the gondola car and $\ddot{\varphi}, \dot{\varphi}, \varphi$, 
the generalised acceleration, speed and displacement of the supporting structure of the gondola car during impact interaction with the grab bucket.

The origin of the coordinate system is located at the centre of mass of the body. The input parameters of the mathematical model are the geometric characteristics of the gondola car body, the parameters of the spring sets of bogies and the parameters of the grab bucket. The solution of the above model was carried out using the Runge-Kutta method in the MathCad software package. The initial displacements and speeds are taken equal to zero [24-26].

The calculation results showed that the acceleration of the supporting structure of the gondola car when struck by a grab bucket is about $3 \mathrm{~m} / \mathrm{s}^{2}$, which is $35 \%$ lower than acceleration values arising in a standard structure. In this case, the coefficient of viscous resistance of the elastomer must be at least $0.3 \mathrm{kN} \mathrm{s} / \mathrm{m}$.

The strength of the improved bearing structure of an open car was calculated. The top cord of an open car with elastomer was modelled as a body with the geometry identical to the inner section of the top cord and the characteristics identical to that of the elastomer (Figure 6). The research was made in the SolidWorks Simulation software using the finite element method [27-30].

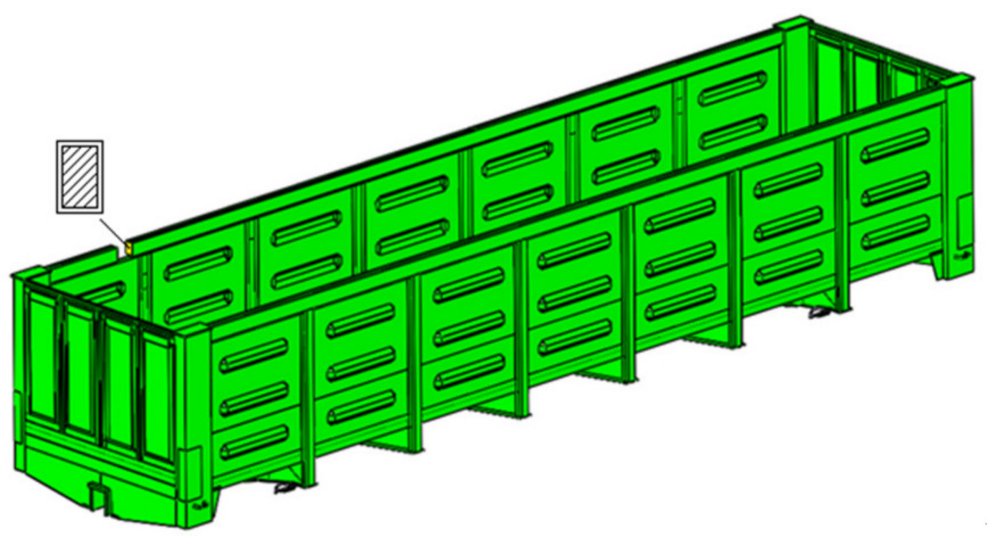

Figure 6. Spatial model of the gondola car supporting structure.

A 12-757 open car was taken as the prototype. Isoparametric tetrahedrons were used as the finite elements. The optimal number of elements in the finite element model was found with the graphic analytical method [31,32]. The method is based on the graphical (geometric) presentation of feasible solutions and the objective function of the problem. The essence of the method is to plot the dependence of the maximum equivalent stresses on the number of finite elements. When this dependence begins to be described by a horizontal line, this is the optimum in the number of finite elements.

The number of elements was 637,118 , the number of nodes was 204,135, the maximum element size was $65.0 \mathrm{~mm}$ and the minimum element size was $13.0 \mathrm{~mm}$. The maximum element side ratio was 651.33. The percentage of elements with a side ratio of less than three was 25.4. The percentage of elements with a side ratio of more than ten was 26.9. The minimum number of elements in a circle was 12. The element size gain ratio was 2.0. The model was secured in the areas of support on the bogies. Steel 09Mn2Si was taken as the structural material.

It was taken that the grab mass was $1800 \mathrm{~kg}$ [33]. In order to simulate the impact interaction of the grab bucket with the upper strapping of the gondola car supporting structure, a pad was installed on it, the geometric parameters of which are equal to the area of contact with the grab bucket (Figure 7). Shock was applied to this pad using SolidWorks Simulation software options. 


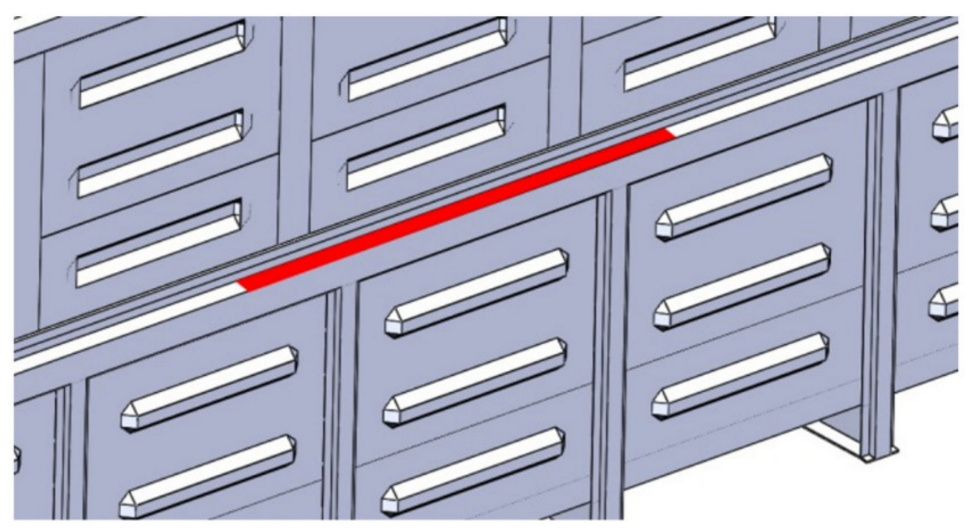

Figure 7. Modelling the contact zone of the grab bucket with the upper strapping of a gondola car.

When creating the design scheme, it was taken into account that the body of the gondola car is subject to a vertical static load due to the weight of the load $P_{v}{ }^{s t}$, the pressure of the expansion of the bulk cargo $P_{b k}$, as well as the load from the grab bucket $P_{g b}$ (Figure 8). At the same time, the blow was considered as absolutely hard. The leaning of the body on the bogies was modelled by placing elastic ties on the centre plates. In this case, the stiffness of the springs is $8000 \mathrm{kN} / \mathrm{m}$, i.e., corresponding to the stiffness of the bogie spring sets $18-100$.

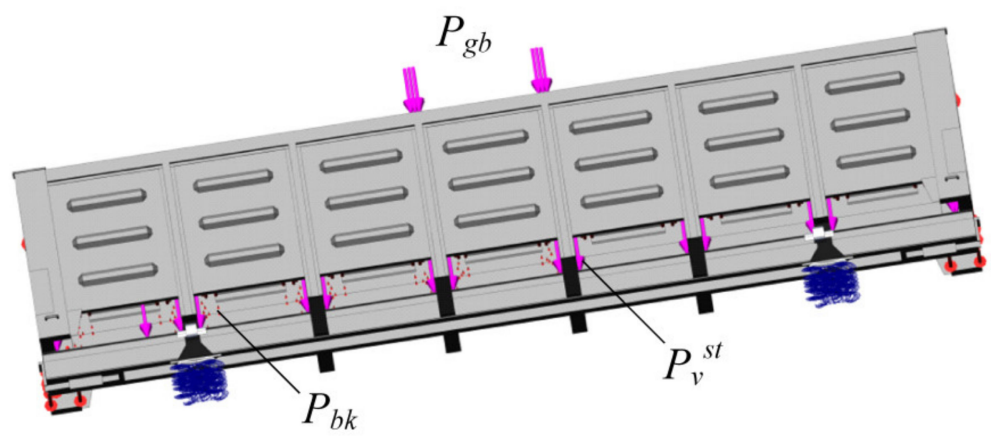

Figure 8. Computational scheme of a gondola car.

The results of the strength calculation for the bearing structure of an open car are given in Figure 9.

The calculation demonstrated that the maximum equivalent stresses in the bearing structure did not exceed the allowable values and amounted to about $320 \mathrm{MPa}$, which is $32 \%$ lower than in the standard design. The maximum displacements were about $20 \mathrm{~mm}$. Thus, the strength of the bearing structure of an open car body with consideration of improvements was provided $[17,18]$. The maximum equivalent stresses in the bearing structure were reduced three times in comparison to those in the typical structure.

Due to the fact that the upper piping is not under the influence of cyclic shock loading from the grab bucket in operation, the calculation for the fatigue of this unit was not carried out. 


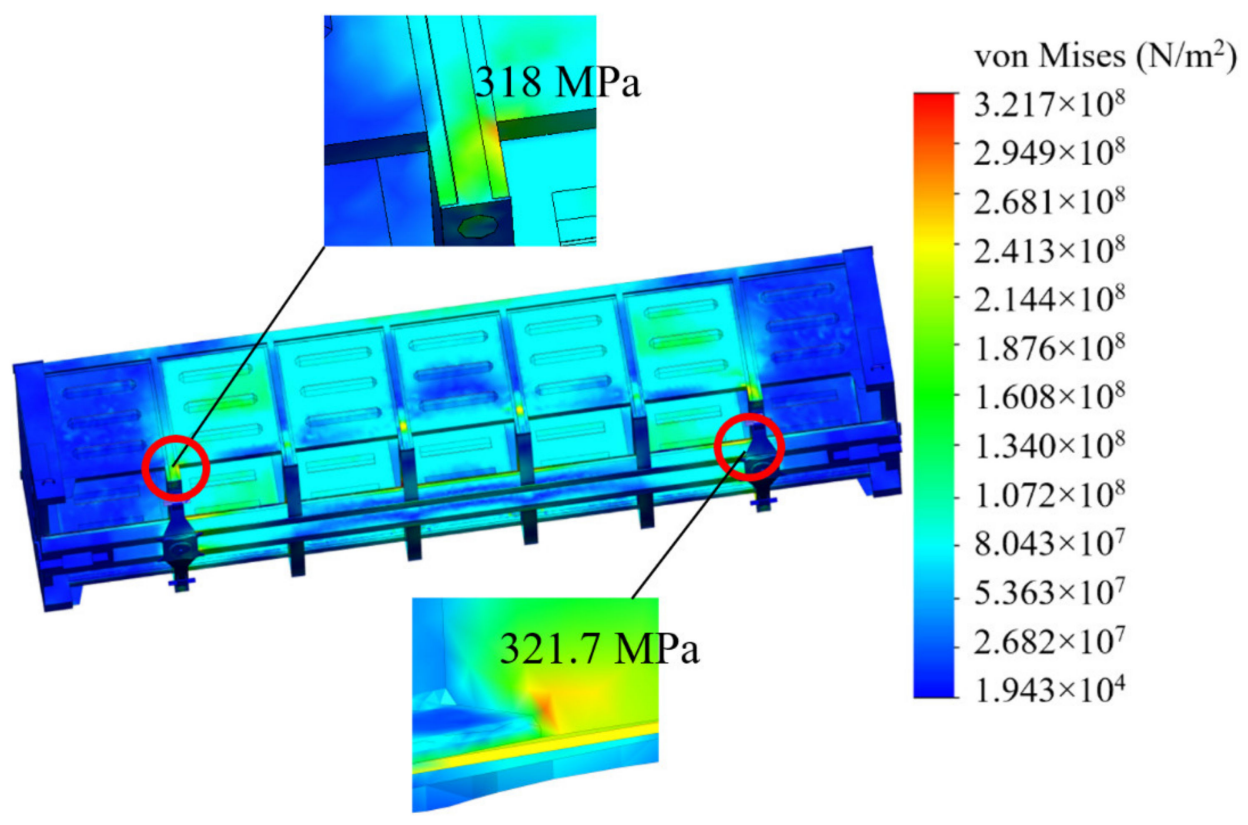

Figure 9. Stress strain state of the bearing structure of an open car body during impact interaction with a grab.

\section{Improvements in the Bearing Structure of an Open Car for Stable Securing on the Train Ferry Deck}

The strength of the bearing structure of an open car body during transportation by train ferries can be provided with a special fixation unit used for securing the body (Figure 10) [25].

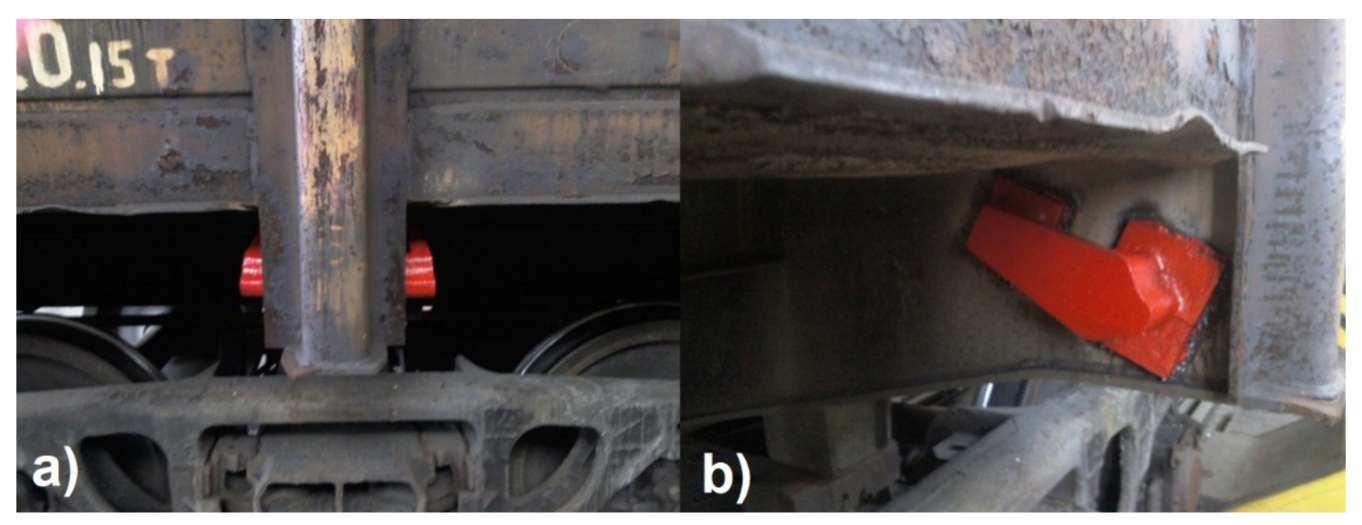

Figure 10. Location of fixation units on the bolster beam for securing a rail car on the deck (a) front view; (b) side view.

The strength of the bearing structure of an open car body was studied with a spatial model. Some reinforcing diaphragms were used on the bolster beam where the fixation units for chain binders were mounted [25].

The design diagram of an open car body during sea disturbance (the highest loads on the bearing structure of a car) included the following forces (Figure 11): vertical static force, $P_{v}{ }^{s t}$; wind force, $P_{w}$; lateral pressure from the freight, $P_{p}$ and force on the body through chain binders, $P_{c}$. Due to the spatial layout of a chain binder, the force through it to the bearing structure of an open car body was decomposed (Figure 12). 


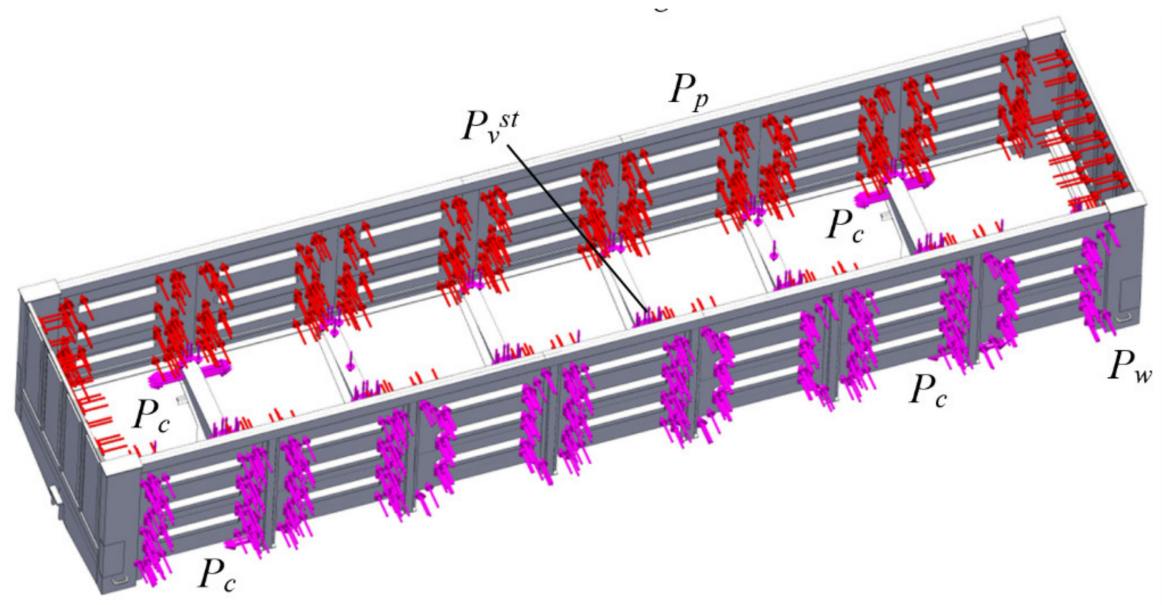

Figure 11. Design diagram of an open car body.

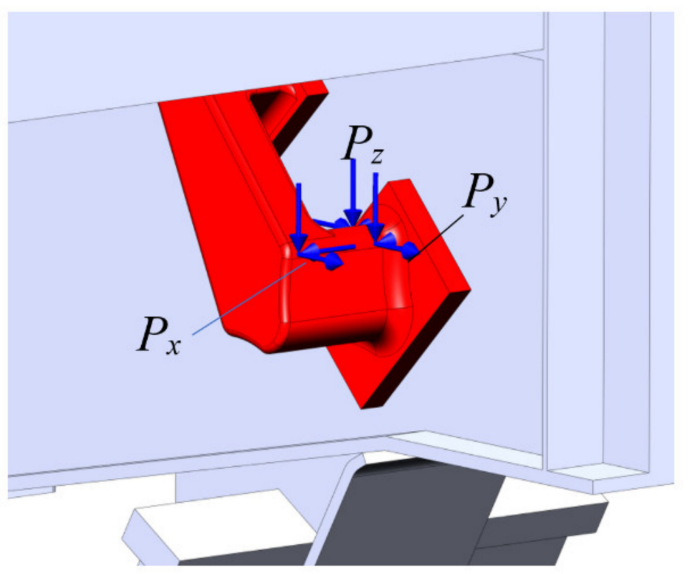

Figure 12. Application of the forces from a chain binder to the fixation unit.

The actual force application to the fixation units for chain binders was modelled by means of mounting special elements (pads), the configuration of which was identical to the geometry of the contact hook area. It ensured the maximum approximation to the actual pattern used for securing an open car on the deck. The numerical values of the forces to the bearing structure of an open car body during sea disturbance are given in Table 1.

Table 1. Forces to the open car body during sea disturbance.

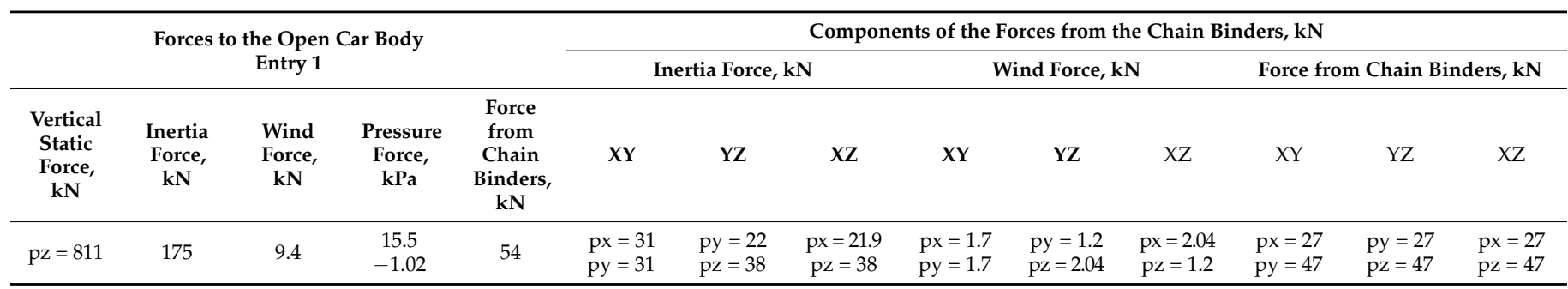

When determining the loads to the open car body the authors took into account that a roll was caused by the static action of the wind to the upper projection of the train ferry loaded with cars on the upper deck. According to the actual hydro-meteorological characteristics of the Black Sea basin, the roll angle was $12.2^{\circ}$.

Additional elements were mounted in the areas of support of an open car body on the centre plates, sliders and stop-jacks. 
The pressure from the bulk freight (black coal) to the walls of an open car was determined using the Coulomb method with Sinelnikov's adjustment [25] as follows:

$$
p=\gamma^{\prime} h^{\prime} \frac{\cos ^{2}\left(\rho^{\prime}+\alpha^{\prime}\right)}{\left[1+\sqrt{\frac{\sin \rho^{\prime} \sin \left(\rho^{\prime} \pm \alpha^{\prime}\right)}{\cos \alpha^{\prime}}}\right] \cos \alpha^{\prime}} g \pm F^{\theta},
$$

where $\gamma^{\prime}$ is the volumetric freight mass, $\mathrm{t} / \mathrm{m}^{3} ; h^{\prime}$ is the height of an open car body, $\mathrm{m} ; \rho^{\prime}$ is the internal friction angle (for ideal bulk freight it equals the angle of natural slope); $\alpha^{\prime}$ is the roll angle of an open car relative to the longitudinal axle, degrees; and $F^{\theta}$ is the additional pressure conditioned by the inertial component acting to the bulk freight at the angular displacements of a train ferry relative to the longitudinal axle, $\mathrm{kPa}$.

The pressure force of the bulk cargo to the side walls of an open car body was taken as a distributed load according to the Simpson's rule with the maximum typical for the actual operation conditions [25-34]. The maximum pressure from the bulk freight to the side wall of an open car body amounted to $15 \mathrm{kPa}$. To determine the inertial loads that are transferred from the chain ties to the supporting structure of the gondola car, mathematical modelling of its dynamic loading during the rolling of the rail ferry was carried out. At the same time, the following mathematical model was created:

$$
\left(\frac{D}{12 g}\left(B^{2}+4 z_{g}^{2}\right)\right) \ddot{\theta}+\left(\Lambda_{\theta} \frac{B}{2}\right) \dot{\theta}=p^{\prime} \frac{h}{2}+\Lambda_{\theta} \frac{B}{2} \dot{F}(t),
$$

where $D$ is the weight displacement of a railway ferry; $B$, the rail ferry width; $h$, the rail ferry board height; $\Lambda_{\theta}$, the vibration resistance coefficient; $z_{g}$, the coordinate of the centre of gravity of the rail ferry; $p^{\prime}$, the wind load and $F(t)$, the course of forces that perturbs the movement of a railway ferry with car bodies placed on its decks. $\ddot{\theta}, \dot{\theta}, \theta$ are the generalised acceleration, speed and movement of a railway ferry loaded with open wagons during rolling. The origin of the coordinate system is located at the centre of mass of the rail ferry.

It was assumed that the body is rigidly fixed on the deck of the ferry and repeats its trajectory of movements during rolling. The shock effect of the sea wave was not considered. The calculation was carried out for the railway ferry "Heroes of Shipki", which moves in the Black Sea. The following parameters of sea waves are taken equally: wave height as $8 \mathrm{~m}$ and period as $9 \mathrm{~s}$ [35]. In this case, the value of the wind load was taken as $1.47 \mathrm{kPa}$ in accordance with the recommendations given in [16]. This source was taken as decisive because it became the primary basis for the formation of requirements for the calculation of wagons for transportation on ferries $[17,18]$.

The calculation results showed that the acceleration that acts on the car body extreme from the bulwark is about $2.4 \mathrm{~m} / \mathrm{s}^{2}$. This acceleration value is considered when determining the inertial load acting on the body from the chain tie. In this case, the angles of the location of the chain tie in space were taken into account (in the $\mathrm{XY}$ and $\mathrm{XZ}$ planes, the tilt angles in accordance with the normative documentation are equal to $60^{\circ}$, and in the $Y Z$ plane to $30^{\circ}$ ).

The finite element model included isoparametric tetrahedrons, the optimal number of which was determined using the graphic analytical method. The number of elements in a mesh was 288,951 , the number of nodes was 94,664 , the maximum element size was $120 \mathrm{~mm}$, the minimum element size was $24 \mathrm{~mm}$, the maximum element side ratio was 571.21 and the percentage of elements with a side ratio of less than three 16 and more than ten was 36.6.

The results of the calculation are given in Figure 13. The research demonstrates that the maximum equivalent stresses are in the radial part of the fixation unit for a chain binder; they amounted to about $300 \mathrm{MPa}$, which is $38 \%$ lower than in the standard design. 


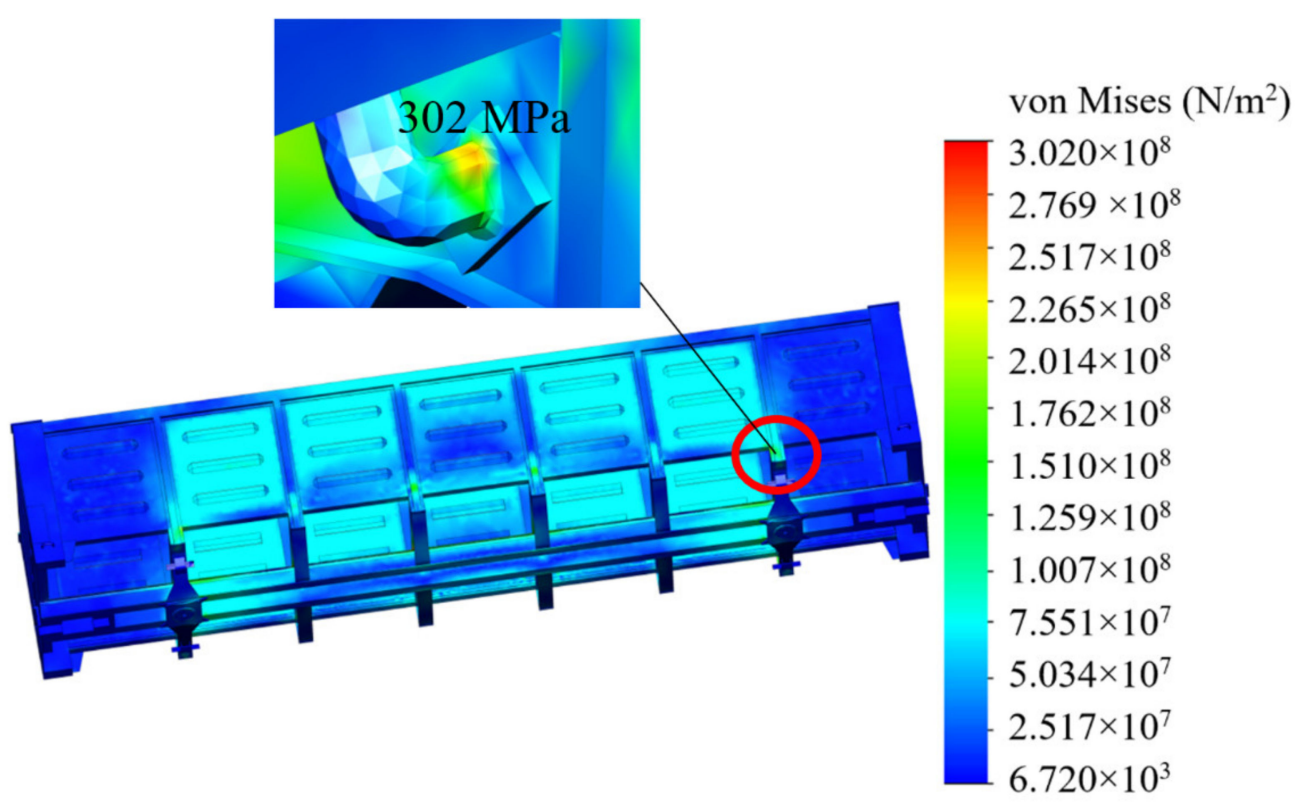

Figure 13. Results of the strength calculation for the bearing structure of an open car body.

The stresses in the vertical sheet of the bolster beam were in the range of $176 \mathrm{MPa}$, and they did not exceed the allowable values for the steel grade of the body frame. The maximum displacements were in the middle part of the side wall of an open car body when it tilted during a roll; they amounted to $5.8 \mathrm{~mm}$.

The research into the fatigue strength of the bearing structure of an open car body transported by a train ferry during sea disturbance was made in the SolidWorks Simulation software. Fatigue analysis is performed in a linear form when stress accumulation is diagnosed. Damage accumulation theory stipulates that an AC stress cycle above the fatigue limit causes damage. The total damage is equal to the sum of the damage caused by individual stress cycles. The test base included $10^{7}$ cycles. The results demonstrated that the strength of an open car body with the consideration of cyclic loads was provided.

The design service life of the bearing structure of an open car body adjusted to train ferry transportation was determined with the following technique given in [36-38]:

$$
T_{n}=\frac{\left(\sigma_{E} /[n]\right)^{m} N_{0}}{B f_{e} \sigma_{a e}^{m}}
$$

where $\sigma_{E}$ is the average strength endurance of a detail, $\mathrm{MPa} ; n$ is the allowable safety factor; $m$ is the fatigue curve rate; $N_{0}$ is the number of tests; $B$ is the coefficient characterising a period of continuous operation of an object, $\mathrm{s} ; f_{e}$ is the effective frequency of dynamic loads, $\mathrm{Hz}$ and $\sigma_{a e}$ is the amplitude of equivalent dynamic stresses, MPa.

The following input parameters were included in the calculation: the average durability limit, taken as 0.5 of the material (steel grades $09 \mathrm{Mn} 2 \mathrm{Cu}$ and $09 \mathrm{Mn} 2 \mathrm{Cu}$ of $172.5 \mathrm{MPa}$ ) the test base cycles (recommended for steel); the continuous operation time for the bearing structure of a body of $1.5 \times 10^{6} \mathrm{~s}$ (based on the actual operation of a train ferry); the effective dynamic load frequency determined by means of the excitation force parameters (for a sea wave) and for waves with a period of $9 \mathrm{~s}$ it equals $0.1 \mathrm{~Hz}$; an admissible safety factor of two; a fatigue curve rate for the welded structure of four and the amplitude of the equivalent dynamic stresses defined through the strength calculation of the stress strain state of the bearing structure of an open car of $176.2 \mathrm{MPa}$.

The design service life of the bearing structure of an open car used for transportation by a train ferry was calculated as about 30 years. 
It should be noted that the actual service life of the fixation unit is longer, because under the normal operation conditions (calm sea or slight sea disturbance) it is loaded with the tension from the chain binders amounting to about $54 \mathrm{kN}$.

Moreover, the appropriate maintenance techniques and diagnostic system can prolong the service life.

\section{Experimental Strength Research of the Improved Bearing Structure of an Open Car}

The strength of the improved bearing structure of an open car was studied during the full-scale bench testing.

The initial stage of the research included the designing of a fixation unit for chain binders. It included the designing and production of a detachable wooden mould for casting the steel elements. The radial lugs and rounded parts of the mould were made of a viscous mixture consisting of liquid glass and chock. Four castings of Steel 32Cr06A with fluidity level $\sigma_{T}=441 \mathrm{MPa}$, rupture stress $\sigma_{B}=638 \mathrm{MPa}$ and relative elongation $\delta=10 \%$ were formed; the strength characteristics were improved by adding Ni together with normalising and hardening. This steel grade is recommended for manufacturing cast pieces in the car building process.

The castings were mechanically treated until they reached the nominal dimensions.

The units were joined to the bolster beam of a car by overlap welding with a double joint (Figure 14) calculated for strength in advance. The units were mounted on side of the bolster beam.

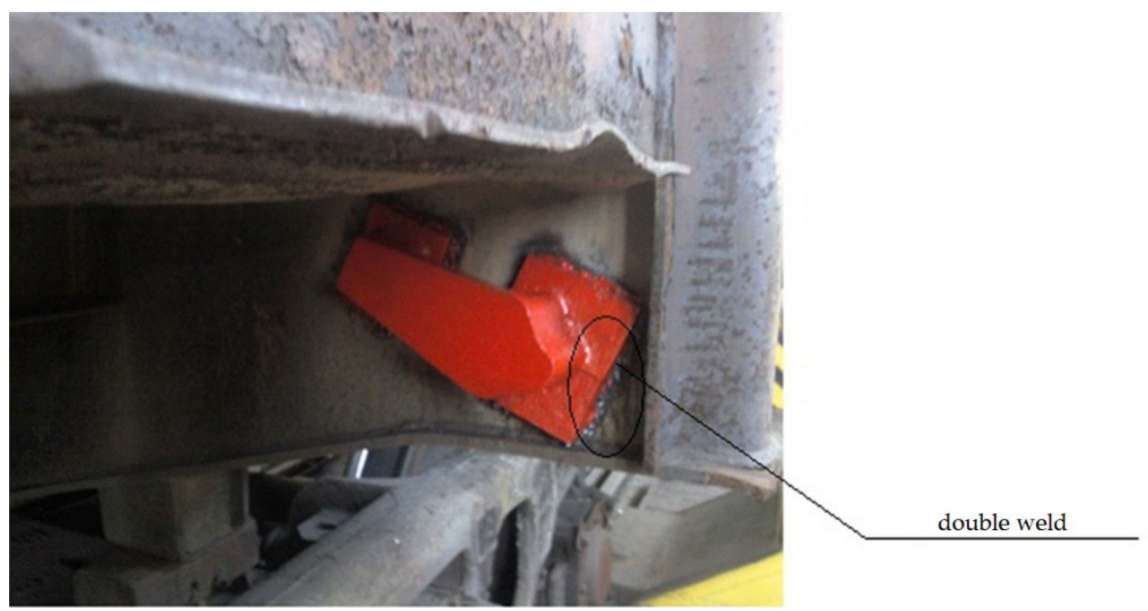

Figure 14. Location of the fixation unit for chain binders on the bolster beam of an open car.

The wire slings with a weight capacity of $196.2 \mathrm{kN}$ were used in designing the chain binders. One end of the sling was fixed on the unit, and the other end was fixed by a bracket welded to the 50-millimeter metal sheet (Figure 15).

The spring suspension was relieved with stationary $294.4 \mathrm{kN}$ jacks, whilst the chain binders and the bolster beam were loaded on side of a car. This diagram modelled the action of the $196.2 \mathrm{kN}$ mechanical jacks to the end support parts of the bolster beams. The forces on the bolster beam were measured with a force gage with a capacity of $196.2 \mathrm{kN}$.

The relative strains in the bolster beam were determined with the classic strain measurement method.

The places for the strain gages were found through theoretical research. As far as the forces on the fixation units for chain binders under the condition of a roll of the train ferry transferred symmetrically, the strain gages were installed on the vertical sheet of one bolster beam (Figure 16). 


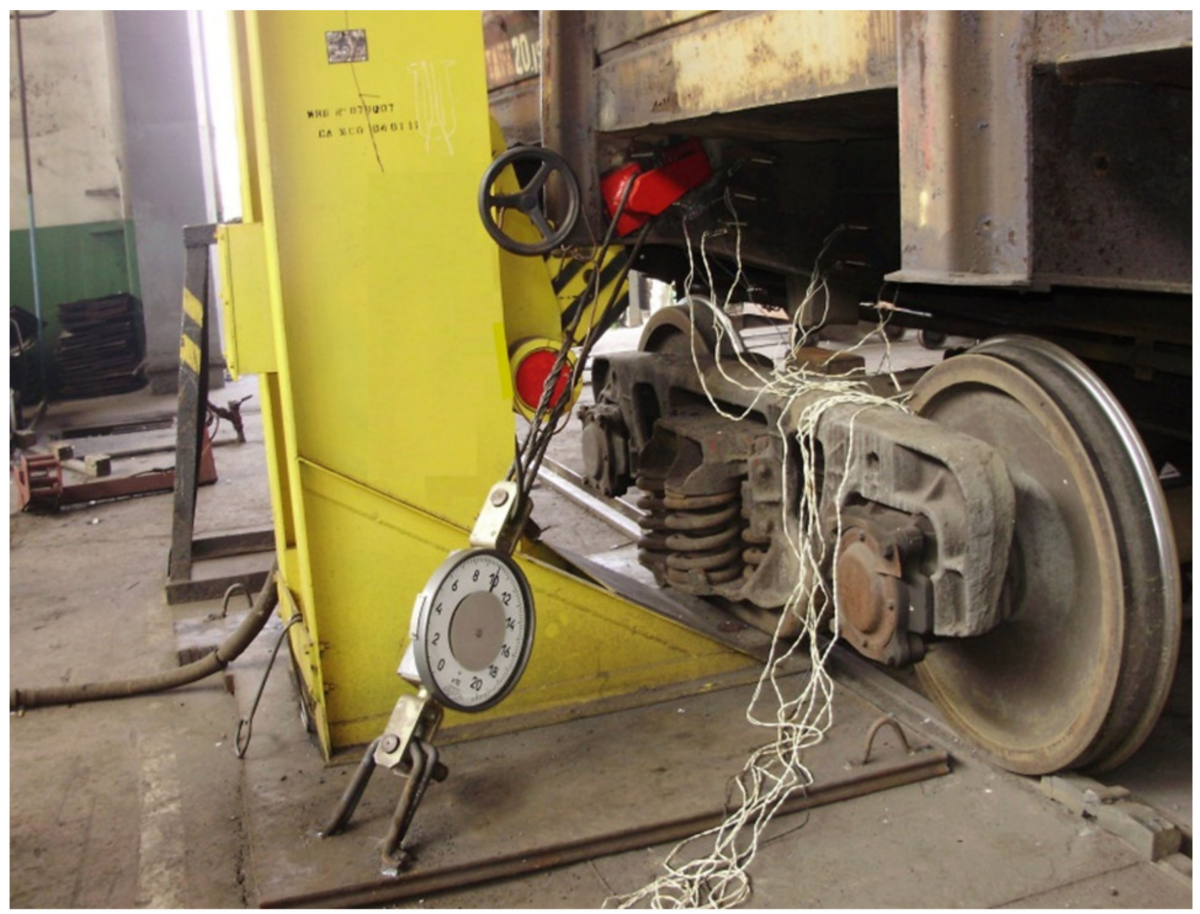

Figure 15. Loading of the fixation unit for chain binders.

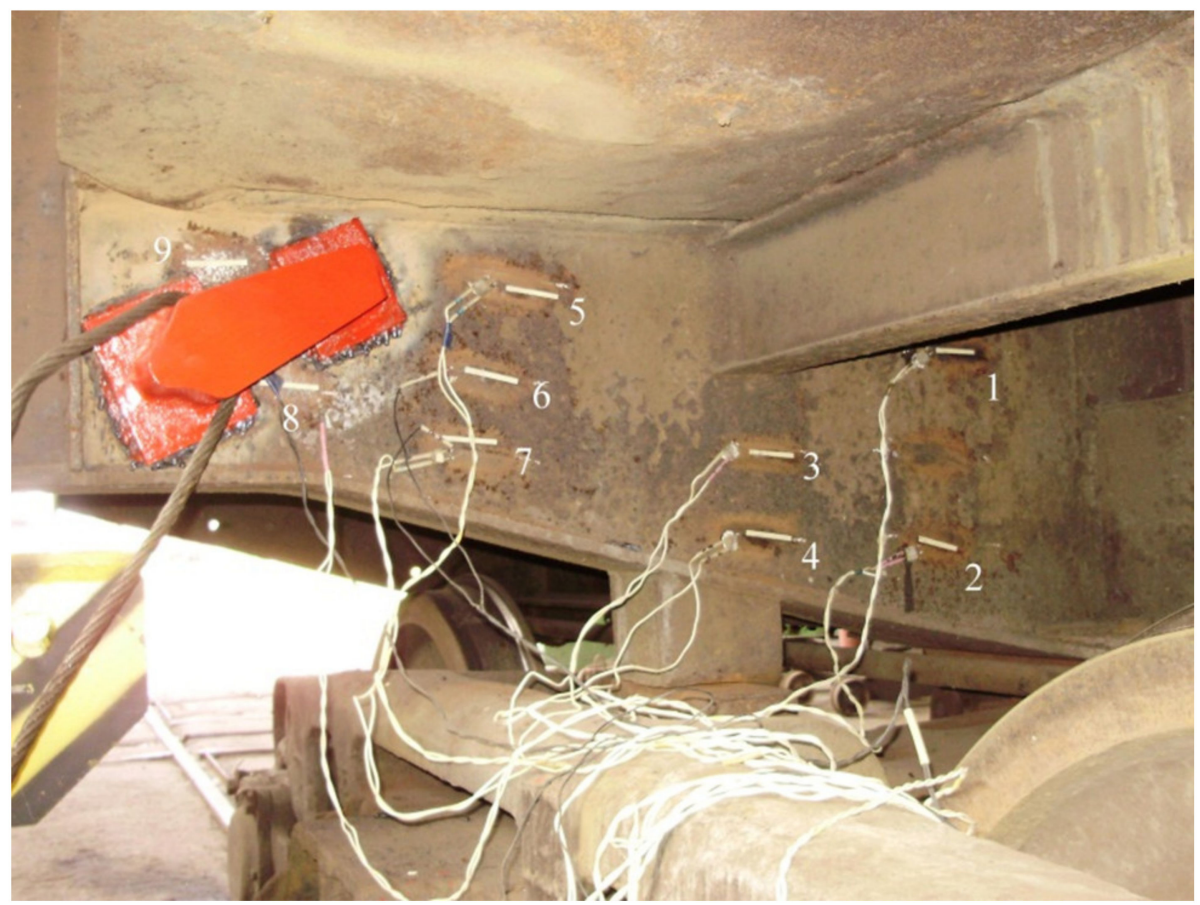

Figure 16. Location of strain gages on the vertical sheet of the bolster beam of a car.

The strain gages were arranged as a Wheatstone bridge. A compensating strain gage was mounted on the homogeneous non-deflecting plate $(09 \mathrm{Mn} 2 \mathrm{Cu}$ ) of a car body (Figure 17). The strain gages were connected in the electric diagram with the $0.5 \mathrm{~mm}^{2}$ wires. 


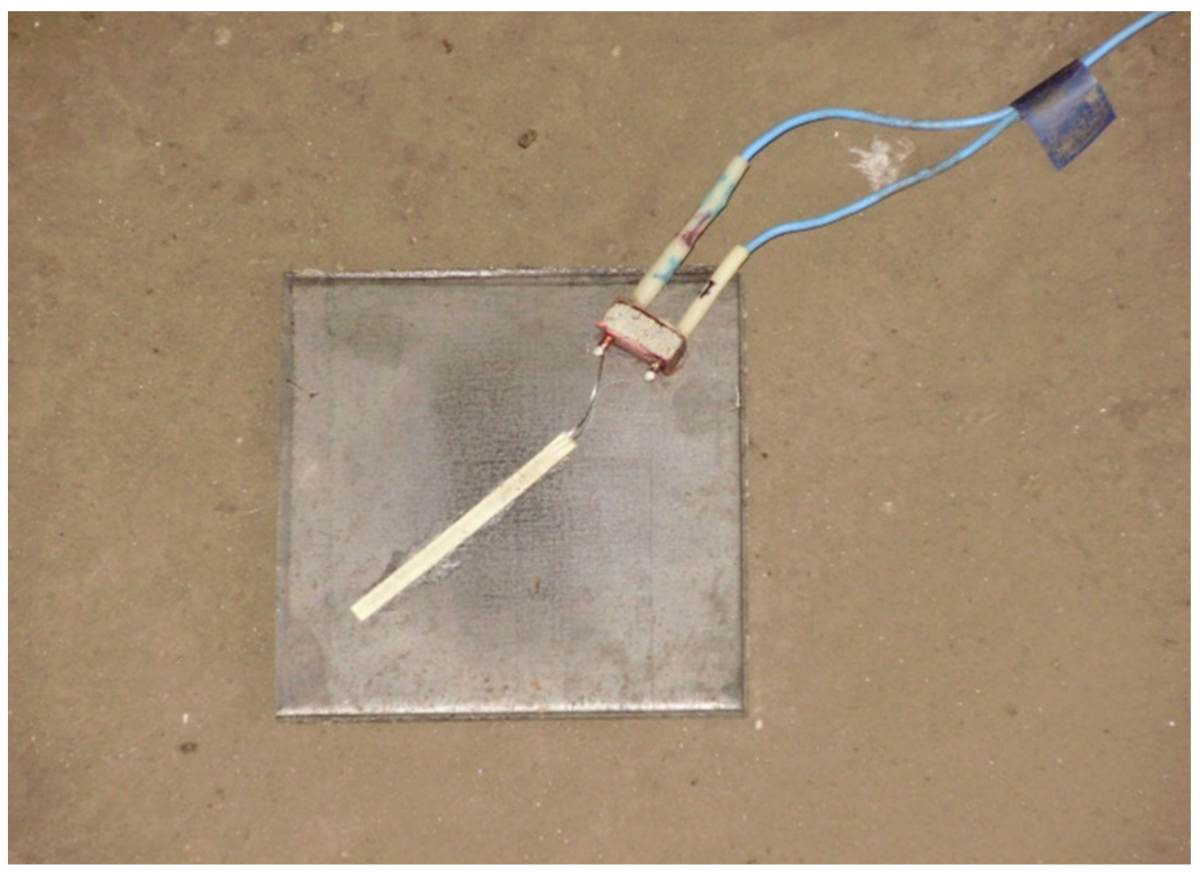

Figure 17. Compensating plate with a strain gage.

The bolster beam was loaded to research the deformations that corresponded to the following forces applied: $49.1 \mathrm{kN}$ were the tension forces of the chain binders; $98.1 \mathrm{kN}$, the forces to the car body through the chain binders at small roll angles (up to 10) and $147.2 \mathrm{kN}$, the forces to the car body through the chain binders at large roll angles (more than 10). Considerable relative deformations were recorded by strain gages No. two, three, four and nine (Figure 16).

Based on the obtained relative deformations, the authors calculated the stresses in the corresponding areas of the bolster beam that showed that the forces from the chain binders through the special fixation units ensured the structural safety factor exceeding two.

The strength of the bolster beam section with strain gages No. three and four can be improved with reinforcing diaphragms.

It should be noted that the experimental research with the strain measurement method has an error conditioned by the metrological parameters of the gages, equipment, connection line, conditions of the experiment and measuring scheme used [39-41].

The measuring error was defined by the following formula:

$$
\Delta \varepsilon=\Delta \varepsilon_{s}+\Delta \varepsilon_{m e}
$$

where $\Delta \varepsilon_{S}$ is the systematic measurement error and $\Delta \varepsilon_{m e}$ the random measurement error.

Here, the systematic measurement error was conditioned by the tolerances for outof-parallelism and the width of a beam of equal bending resistance, and in accordance with [41] for the standard beam, it amounts to $4 \%$.

A random measurement error is defined by the following formula:

$$
\Delta \varepsilon=\frac{\varepsilon_{a}}{\varepsilon_{e}}
$$

where $\varepsilon_{a}$ is the absolute measurement error and $\varepsilon_{e}$ is the error obtained in the experimental research. The research results showed that the value was $8.8 \%$ and the total error was $12.8 \%$.

It is important to note that these values of errors can be reduced by using smaller tolerances for non-parallelism and the thickness of the calibration bar. At the same time, based on the practical experience of conducting experimental studies using the method of electrical strain gauging by the authors of the article, this error is acceptable. 


\section{Conclusions}

This research presented measures to improve the strength of the bearing structure of a car during unloading with a grab. The authors suggested the introduction of viscous elements in the structure. An elastomer can be taken as the viscous element and the damper during the impact interaction between the top cord and the grab.

The maximum equivalent stresses in the bearing structure of an open car amounted to about $320 \mathrm{MPa}$, which is $32 \%$ lower than in the standard design. The maximum displacements were about $20 \mathrm{~mm}$. Thus, the strength of the improved bearing structure of an open car body was provided. It should be noted that the maximum equivalent stresses in the bearing structure were reduced three times in comparison to those of the typical structure.

The authors suggested measures to adjust the bearing structure of a car for tight securing on the train ferry deck by means of a special unit for the fixation of the chain binders mounted on bolster beams of the frame.

The maximum equivalent stresses were recorded in the radial part of the fixation unit for chain binders. They amounted to about $300 \mathrm{MPa}$, which is $38 \%$ lower than in the standard design. The stresses in the vertical sheet of the bolster beam were in the range of up to $176 \mathrm{MPa}$. They did not exceed the allowable values for the steel grade of the body frame.

This study dealt with the determination of the design service life of the bearing structure of an open car with the consideration of its regular use for train ferry transportation. The design service life amounted to about 30 years.

The research also included the determination of the strength of the bearing structure of a car with consideration of the improvements suggested. The full-scale testing was based on the strain measurement method. The most loaded areas of the bolster beam of an open car were found. The error of the experiments was $8.8 \%$.

The results of the research may be used by those who aim to achieve the higher operational efficiency of cars during rail/sea transportation.

Author Contributions: Conceptualisation, O.F. and A.L.; methodology, O.F.; software, V.P.; validation, A.L., V.P. and P.K.; formal analysis, A.L.; investigation, P.K.; resources, O.F.; data curation, V.P.; writing—original draft preparation, O.F.; writing—review and editing, A.L.; visualisation, V.P.; supervision, P.K.; project administration, A.L.; funding acquisition, A.L. All authors have read and agreed to the published version of the manuscript.

Funding: The authors gratefully acknowledge funding from the specific research on "Innovative principles for creating resource-saving structures of railroad cars based on the refined dynamic loads and functionally adaptive flash-concepts", which is funded from the state budget of Ukraine in 2020. The authors also gratefully acknowledge funding from the specific research on BUT FSI-S-20-6267.

Institutional Review Board Statement: Not Applicable.

Informed Consent Statement: Not Applicable.

Data Availability Statement: Not Applicable.

Acknowledgments: The authors thank to the Ukrainian State University of Railway Transport, State University of Infrastructure and Technologies and Brno University of Technology for support.

Conflicts of Interest: The authors declare no conflict of interest.

\section{References}

1. Št'astniak, P.; Moravčík, M.; Smetanka, L. Investigation of strength conditions of the new wagon prototype type Zans. MATEC Web Conf. 2019, 254, 02037. [CrossRef]

2. Slavchev, S.; Stoilov, V.; Purgic, S. Static strength analysis of the body of a wagon, series Zans. J. Balk. Tribol. Assoc. 2015, 21, 49-57.

3. Harak, S.S.; Sharma, S.C.; Harsha, S.P. Structural dynamic analysis of freight railway wagon using finite element method. Procedia Mater. Sci. 2014, 6, 1891-1898. [CrossRef]

4. Krason, W.; Niezgoda, T. FE numerical tests of railway wagon for intermodal transport according to PN-EU standards. Bull. Pol. Acad. Sci. Tech. Sci. 2014, 62, 843-851. [CrossRef] 
5. Neduzha, L.O.; Shvets, A.A. Theoretical and experimental research of strength qualities of a backbone of a freight wagon. Sci. Prog. Transport. Bull. Dnipropetr. Natl. Univ. Railw. Transp. 2018, 73, 131-147. Available online: http://nbuv.gov.ua/UJRN/ vdnuzt_2018_1_15 (accessed on 12 August 2021). (In Ukrainian)

6. Boronenko, Y.P.; Filipova, I.O. Choice of constructive decisions of elements of wagons with small weight of container. Sci. Prog. Transport. Bull. Dnipropetr. Natl. Univ. Railw. Transp. 2017, 69, 121-129. (In Ukrainian) [CrossRef]

7. Milovanovic, V.; Dunic, V.; Rakic, D.; Zivkovic, M. Identification causes of cracking on the underframe of wagon for containers transportation-Fatigue strength assessment of wagon welded joints. Eng. Fail. Anal. 2013, 31, 118-131. [CrossRef]

8. Fomin, O.; Lovska, A.; Píštěk, V.; Kučera, P. Dynamic load effect on the transportation safety of tank containers as part of combined trains on railway ferries. In Proceedings of the Vibroengineering Procedia 2019, Greater Noida, India, 28-30 November 2019; pp. 124-129. [CrossRef]

9. Fomin, O.; Lovska, A.; Masliyev, V.; Tsymbaliuk, A.; Burlutski, O. Determining strength indicators for the bearing structure of a covered wagon's body made from round pipes when transported by a railroad ferry. East. Eur. J. Enterp. Technol. 2019, 1, 33-40. [CrossRef]

10. Bulychev, M.A.; Antipin, D.Y. Improving the method of calculating the strength of the upper strapping of the side walls of gondola cars. Bull. Bryansk State Tech. Univ. 2019, 3, 58-64. (In Russian) [CrossRef]

11. Chepurchenko, I.V.; Nosirev, D.Y.; Korkina, S.V. Using the theory of optimal design for improving the body structure of a blind gondola car. Bull. Transp. Volga Reg. 2018, 3, 28-32. (In Russian)

12. Boronenko, Y.P.; Filipova, I.O. The choice of design solutions for the elements of cars with a low tare weight. Science and progress in transport. Bull. Dnipropetr. Natl. Univ. Railw. Transp. 2017, 3, 121-129. (In Russian) [CrossRef]

13. Vizniak, R.I.; Chepurchenko, I.V.; Yatsenko, A.O. Specifics of determining the operational loads of a gondola car and ways to improve its design in order to ensure its strength and safety. Collect. Sci. Work. Ukr. State Univ. Railw. Transp. 2016, 159, 91-97. (In Ukrainian)

14. Kebal, I.Y.; Myamlin, S.V. Improving the design of the hatch cover of the gondola. Wagon Park 2016, 7-8, 41-43. (In Russian)

15. Myamlin, S.V.; Baranovsky, D.N.; Kebal, I.Y. The hatch cover of the universal gondola car. Bull. Sci. Work. Bryansk Branch Mosc. Inst. Transp. Eng. 2015, 7, 45-48. (In Russian)

16. Zemlezin, I.N. Methodology for calculating and studying the forces acting on a wagon during transportation by sea ferries. Transport: Moscow, Russia, 1970. (In Russian)

17. DSTU 7598:2014. Freight Cars. General Requirements for Calculations and Design of New and Modernized Wagons of Track 1520 mm (Non-Self-Propelled); State Ukrainian Research Institute of Wagon Building (UkrNDIV): Kiev, Ukraine, 2015; 162p. Available online: http:/ / online.budstandart.com/ua/catalog/doc-page.html?id_doc=73763 (accessed on 31 May 2021). (In Ukrainian)

18. GOST 33211-2014. Cargo Wagons. Requirements for Strength and Dynamic Properties; Naukno-Issledovatelsky instite of railway transport: Moscow, Russia, 2016; p. 54. Available online: https:/ / docs.cntd.ru/document/1200121493 (accessed on 31 May 2021). (In Russian)

19. Navigation Maritime Bulgare. Cargo Secuaring Menual m/v "Geroite na Sevastopol"; Navigation Maritime Bulgare: Varna, Bulgaria, 1997. Available online: https:/ /www.marinetraffic.com/en/ais/details/ships/shipid:120037/mmsi:207008000/imo:7529976/ vessel:GEROITE_NA_SEVASTOPOL (accessed on 12 August 2021). (In Bulgarian)

20. Shmakov, M.G. Special Ship Devices; Shipbuilding: Leningrad, Russia, 1975. (In Russian)

21. Fomin, O.; Lovska, A.; Píštěk, V.; Kučera, P. Dynamic load computational modelling of containers placed on a flat wagon at railroad ferry transportation. In Proceedings of the Vibroengineering Procedia 2019, Greater Noida, India, 28-30 November 2019; pp. 118-123. Available online: https:/ / www.jvejournals.com/article/21132 (accessed on 12 August 2021).

22. Fomin, O.; Gerlici, J.; Lovskaya, A.; Kravchenko, K.; Burlutski, O.; Hauser, V. Peculiarities of the mathematical modelling of dynamic loading on containers in flat wagons transportation. In Proceedings of the MATEC Web of Conferences, EDP Sciences, Paris, France, 21-23 August 2019; p. 254.

23. Parkhomenko, L.; Viznyak, R.; Skurikhin, D.; Eiduks, J. Railway-ferry crossings of Ukraine and Baltics as an efficient link of the Baltic-Black Sea transport corridor. In Lecture Notes in Intelligent Transportation and Infrastructure: ICTE in Transportation and Logistics; Springer International Publishing: New York, NY, USA, 2019; p. 402.

24. Kelrykh, M.; Fomin, O. Perspective directions of planning carrying systems of gondolas. Metall. Min. Ind. 2014, 6, 64-67.

25. Lovska, A. Peculiarities of computer modeling of strength of body bearing construction of gondola car during transportation by ferry-bridge. Metall. Min. Ind. 2015, 1, 49-54.

26. Bychkov, A.S.; Kondratiev, A.V. Criterion-based assessment of performance improvement for aircraft structural parts with thermal spray coatings. J. Superhard Mater. 2019, 41, 53-59. [CrossRef]

27. Lovska, A.; Fomin, O. A new fastener to ensure the reliability of a passenger coach car body on a railway ferry. Acta Polytech. 2020, 60, 478-485. [CrossRef]

28. Fomin, O.V.; Lovska, A.O.; Plakhtii, O.A.; Nerubatskyi, V.P. The influence of implementation of circular pipes in load-bearing structures of bodies of freight cars on their physico-mechanical properties. Sci. Bull. Natl. Min. Univ. 2017, 6, 89-96.

29. Lovska, A. Simulation of loads on the carrying structure of an articulated flat car in combined transportation. Int. J. Eng. Technol. 2018, 7, 140-146. [CrossRef]

30. Fomin, O. Modern requirements to carrying systems of railway general-purpose gondola cars. Metall. Min. Ind. 2014, 5, 31-43. 
31. Vatulia, G.L.; Lobiak, O.V.; Deryzemlia, S.V.; Verevicheva, M.A.; Orel, Y.F. Rationalization of cross-sections of the composite reinforced concrete span structure of bridges with a monolithic reinforced concrete roadway slab. In Proceedings of the IOP Conference Series: Materials Science and Engineering, 11th International Scientific Conference on Aeronautics, Automotive and Railway Engineering and Technologies, Sozopol, Bulgaria, 10-12 September 2019; Volume 664, pp. 1-9. [CrossRef]

32. Vatulia, G.; Komagorova, S.; Pavliuchenkov, M. Optimization of the truss beam. Verification of the calculation results. MATEC Web Conf. 2018, 230, 02037. [CrossRef]

33. DSTU GOST 22235:2015. Freight Wagons of Main-Line Railways of 1520 mm Gauge. General Requirements for Ensuring Safety during Loading and Unloading and Shunting Operations; BUDSTANDART Online: Sumy, Ukraine, 2015; p. 24. Available online: http:/ / online.budstandart.com/ru/catalog/doc-page?id_doc=63882 (accessed on 28 July 2021). (In Ukrainian).

34. Lovska, A.O. Computer simulation of wagon body bearing structure dynamics during transportation by train ferry. East. Eur. J. Enterp. Technol. 2015, 3, 9-14. [CrossRef]

35. Lopatukhin, L.I.; Bukhanovsky, A.V.; Ivanov, S.V.; Chernysheva, E.S. Reference Data on the Regime of Wind and Waves of the Baltic, North., Black, Azov and Mediterranean Seas; Russian Maritime Register of Shipping: St. Petersburg, Russia, 2006. Available online: https: / / files.stroyinf.ru/Data2/1/4293747/4293747775.pdf (accessed on 28 July 2021). (In Russian)

36. Fomin, O.; Lovska, A. Establishing patterns in determining the dynamics and strength of a covered freight car, which exhausted its resource. East. Eur. J. Enterp. Technol. 2020, 6, 21-29. [CrossRef]

37. Ustich, P.A.; Karpych, V.A.; Ovechnikov, M.N. Reliability of Rail Non-Traction Rolling Stock; raillook.com: Moscow, Russia, 1999; p. 415. Available online: https://raillook.com/materialy/transport/jeleznodorojniy/vagony-i-vagonnoe-hozyaistvo/2004 -nadezhnost-relsovogo-netyagovogo-podvizhnogo-sostava-p-a-ustich-v-a-karpyshev-m-n-ovechnikov/ (accessed on 31 May 2021). (In Russian).

38. Fomin, O.; Kulbovsky, I.; Sorochinska, E.; Supernova, S.; Bambura, O. Experimental confirmation of the theory of implementation of the coupled design of center girder of the hopper wagons for iron ore pellets. East. Eur. J. Enterp. Technol. 2017, 5, 11-18. [CrossRef]

39. Lovska, A.; Fomin, O.; Píštěk, V.; Kučera, P. Dynamic load modelling within combined transport trains during transportation on a railway ferry. Appl. Sci. 2020, 10, 5710. [CrossRef]

40. Lovska, A.; Fomin, O.; Kučera, P.; Píštěk, V. Calculation of loads on carrying structures of articulated circular-tube wagons equipped with new draft gear concepts. Appl. Sci. 2020, 10, 7441. [CrossRef]

41. Makarov, R.A. Strain Gauge in Mechanical Engineering; Machine-stroitechet library: Moscow, Russia, 1975; p. 288. Available online: https: / /lib-bkm.ru/12987 (accessed on 2 June 2021). (In Russian) 